S

Page 1 of

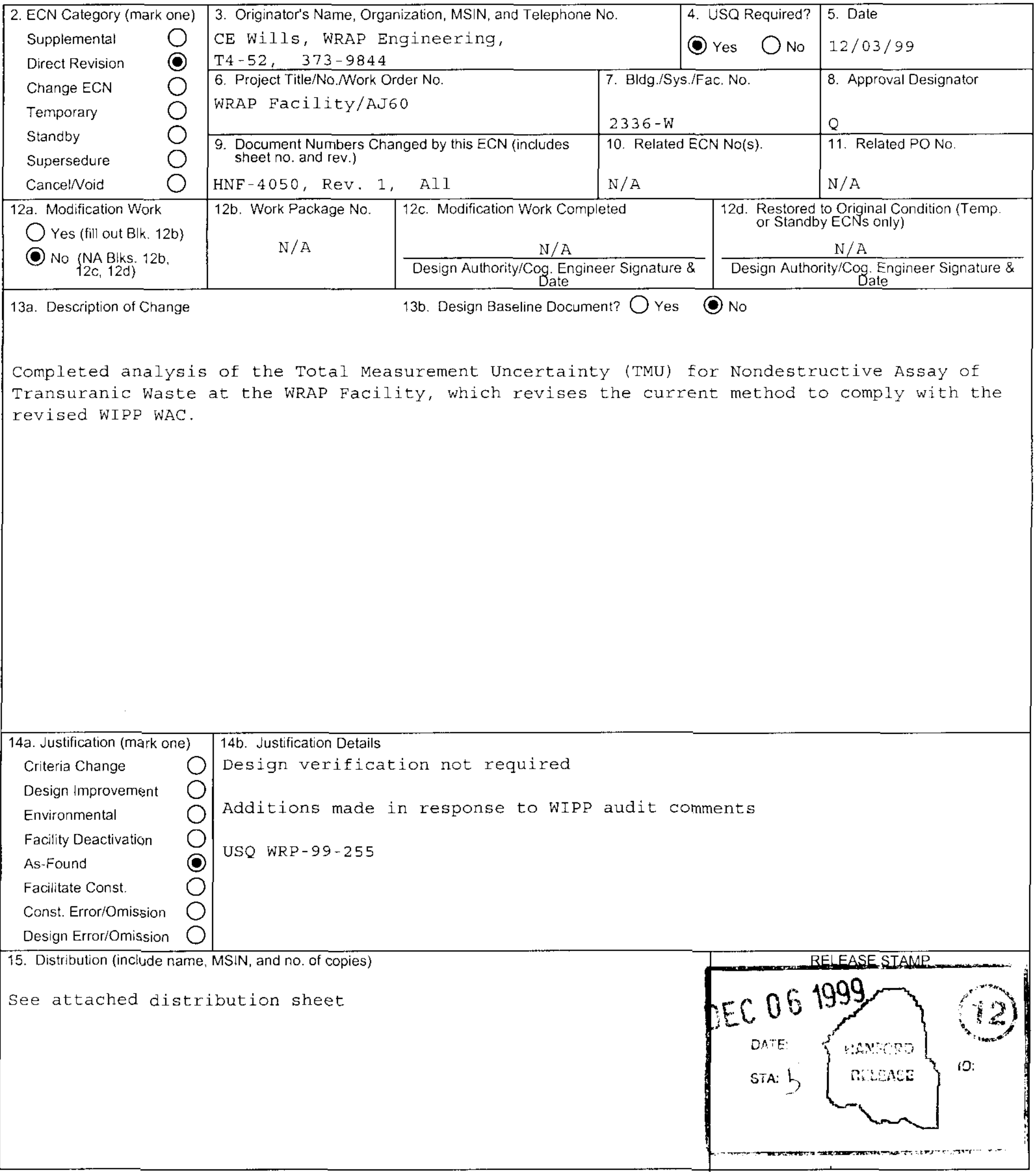




\section{ENGINEERING CHANGE NOTICE}

16. Design Verification Required

$\bigcirc$ Yes

(O) No

17. Cost Impact
ENGINEERING
Additional $\bigcirc \$ \frac{N / A}{\text { Savings } O} \$ \frac{N / A}{}$

Page 2 of 2

\section{CONSTRUCTION}

Additional $\bigcirc \$ \mathrm{~N} / \mathrm{A}$

Savings $\bigcirc \$ N / A$
1. ECN (use no. from pg. 1)

$\mathrm{ECN}-655108$

18. Schedule Impact (days)

Improvement

O N/A

Delay

$\bigcirc N / A$

19. Change Impact Review: Indicate the related documents (other than the engineering documents identified on Side 1) that will be affected by the change described in Block 13 . Enter the affected document number in Block 20 .

$\begin{array}{ll}\text { SDD/DD } & \text { Seismic/Stress Analysis } \\ \text { Functional Design Criteria } & \text { Stress/Design Report } \\ \text { Operating Specification } & \text { Interface Control Drawing } \\ \text { Criticality Specification } & \text { Calibration Procedure } \\ \text { Conceptual Design Report } & \text { Installation Procedure } \\ \text { Equipment Spec. } & \text { Maintenance Procedure } \\ \text { Const. Spec. } & \text { Opgineering Procedure } \\ \text { Procurement Spec. } & \text { Operating Procedure } \\ \text { Vendor Information } & \text { IEFD Drawing } \\ \text { OM Manual } & \text { Cell Arrangement Drawing } \\ \text { FSAR/SAR } & \text { Essential Material Specification } \\ \text { Radiation Work Permit } & \text { Fac. Proc. Samp. Schedule } \\ \text { Environmental Impact Statement } & \text { Inspection Plan }\end{array}$

\begin{tabular}{ll}
$\square$ & Tank Calibration Manual \\
$\square$ & Heaith Physics Procedure \\
$\square$ & Test Procedures/Specification \\
$\square$ & Component Index \\
$\square$ & AsME Coded Item \\
$\square$ & Computer Software \\
$\square$ & Electric Circuit Schedule \\
$\square$ & Process Control Manual/Plan \\
$\square$ & Process Flow Chart \\
$\square$ & Purchase Requisition \\
$\square$ & Tickler File \\
\hline
\end{tabular}

$\square$
$\square$
$\square$
$\square$
$\square$
$\square$
$\square$
$\square$
$\square$
$\square$
$\square$
$\square$
$\square$
$\square$
$\otimes$
$\square$

20. Other Affected Documents: (NOTE: Documents listed below will not be revised by this ECN.) Signatures below indicate that the signing organization has been notified of other affected documents listed below.

None

Design Authority

Cog. Eng. CE Wills

Cog. Mgr. IR Weidert

QA

Safety

Environ.

Other

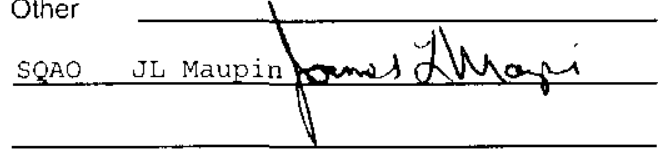

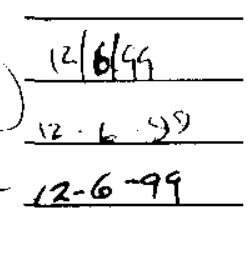

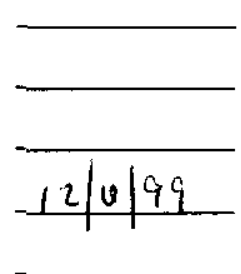

Design Agent

$P E$

QA

Safety

Design

Environ.

Other

\section{DEPARTMENT OF ENERGY}

Signature or a Control Number that tracks the Approval Signature

\section{ADDITIQNAL}




\section{DISTRIBUTION SHEET}

\begin{tabular}{|c|c|c|c|c|c|}
\hline To & \multirow{2}{*}{\multicolumn{3}{|c|}{$\begin{array}{l}\text { From } \\
\text { WRAP Lng ineer ing }\end{array}$}} & \multicolumn{2}{|l|}{ Page 1 of 1} \\
\hline Distribution & & & & \multicolumn{2}{|c|}{ Date $12 / 03 / 99$} \\
\hline \multicolumn{4}{|l|}{ Project Title/Work Order } & \multicolumn{2}{|c|}{ EDT No. $N / \Lambda$} \\
\hline \multicolumn{4}{|c|}{$\begin{array}{l}\text { TOTAL MFASURFMFNT UNCFRTAINTY FOR NDA OF TRU WASTF AT THF WRAP } \\
\text { FACILITY }\end{array}$} & \multicolumn{2}{|c|}{ ECN No. $\quad[C N-655108$} \\
\hline Name & MSIN & $\begin{array}{l}\text { Text } \\
\text { With All } \\
\text { Attach. }\end{array}$ & Text Only & $\begin{array}{l}\text { Attach./ } \\
\text { Appendix } \\
\text { Only }\end{array}$ & $\begin{array}{l}\text { EDT/ECN } \\
\text { Only }\end{array}$ \\
\hline
\end{tabular}

W'a Jasen

JK Kersten

JA Maupir

MA Purcel1

WR Thackaberry

CE Iaylor

JR weidert

CE WiThs

LOL /RL Reading Room

Engineering files
T4-05 $x$

T4-5? $\quad x$

T4-06 $\quad x$

$16-50 \quad x$

T4- 52

$14-52$

T4-52 $x$

T4-52 $\quad X$

$H 2-53 \quad x$

B1-07 $\quad X$

\section{X}

$x$ 


\title{
Total Measurement Uncertainty For Nondestructive Assay of Transuranic Waste At the WRAP Facility
}

\author{
CE Wills \\ U.S. Department of Energy Contract DE-AC06-96RL13200
EDT/ECN: $\quad$ ECN-655108 UC: 506
Org Code: $32600 \quad$ Charge Code: AJ60 \\ B\&R Code: EW02J16 Total Pages: 24
}

Waste Management Federal Services of Hanford, Inc., Richland. WA 99352

Key words: TMU, NDA, WIPP, TRU, CAO

Abstract: This report examines the contributing factors to NDA measurement uncertainty at WRAP. The significance of each factor on the TMU is analyzed, and a final method is given for determining the TMU for NDA measurements at WRAP. As more data becomes available, and WRAP gains in operational experience, this report will be reviewed semiannually and updated as necessary.

** GENIC-PC is a registered trademark of Digital Equipment Corporation. Huston, TX.

** MGA Software is a registered trademark of Mitchel1 \& Gauthier Associates, Inc., Concord. MA.

TRADEMARX DISCLAIMER. Reference herein to any specific comercial product, process, or service by trade name, trademark, manufacturer, or otherwise, does not necessarily constitute or imply its endorsement, recommendation, or favoring by the United States Government or any agency thereof or its contractors or subcontractors.

Printed in the United States of America. To obtain copies of this document, contact: Document Control Services, P.0. Box 950. Mailstop H6-08, Richland WA 99352, Phone (509) 372-2420; Fax (509) 376-4989.
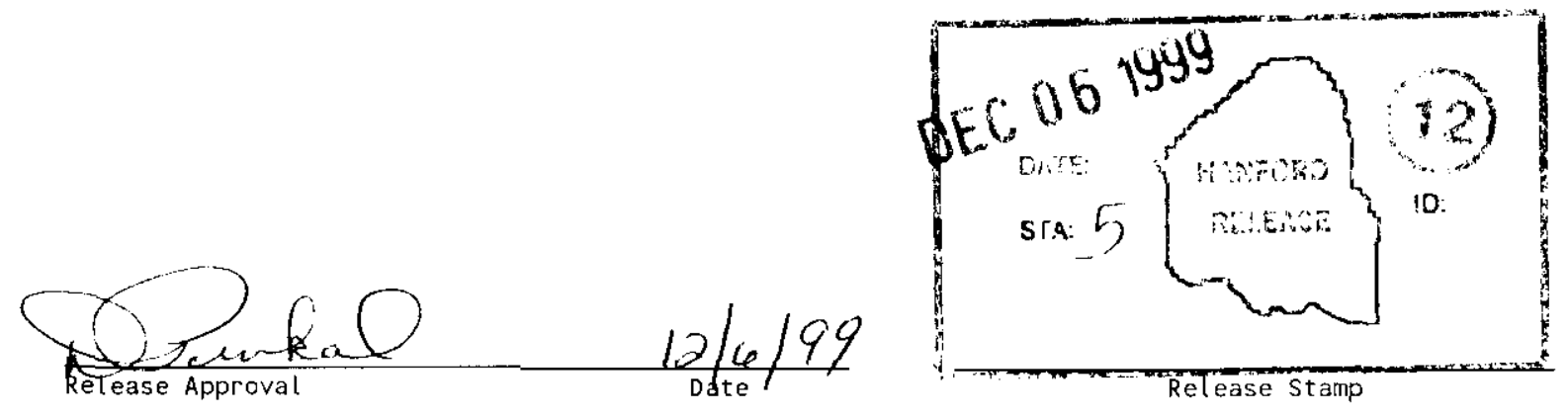

\section{Approved for Public Release}




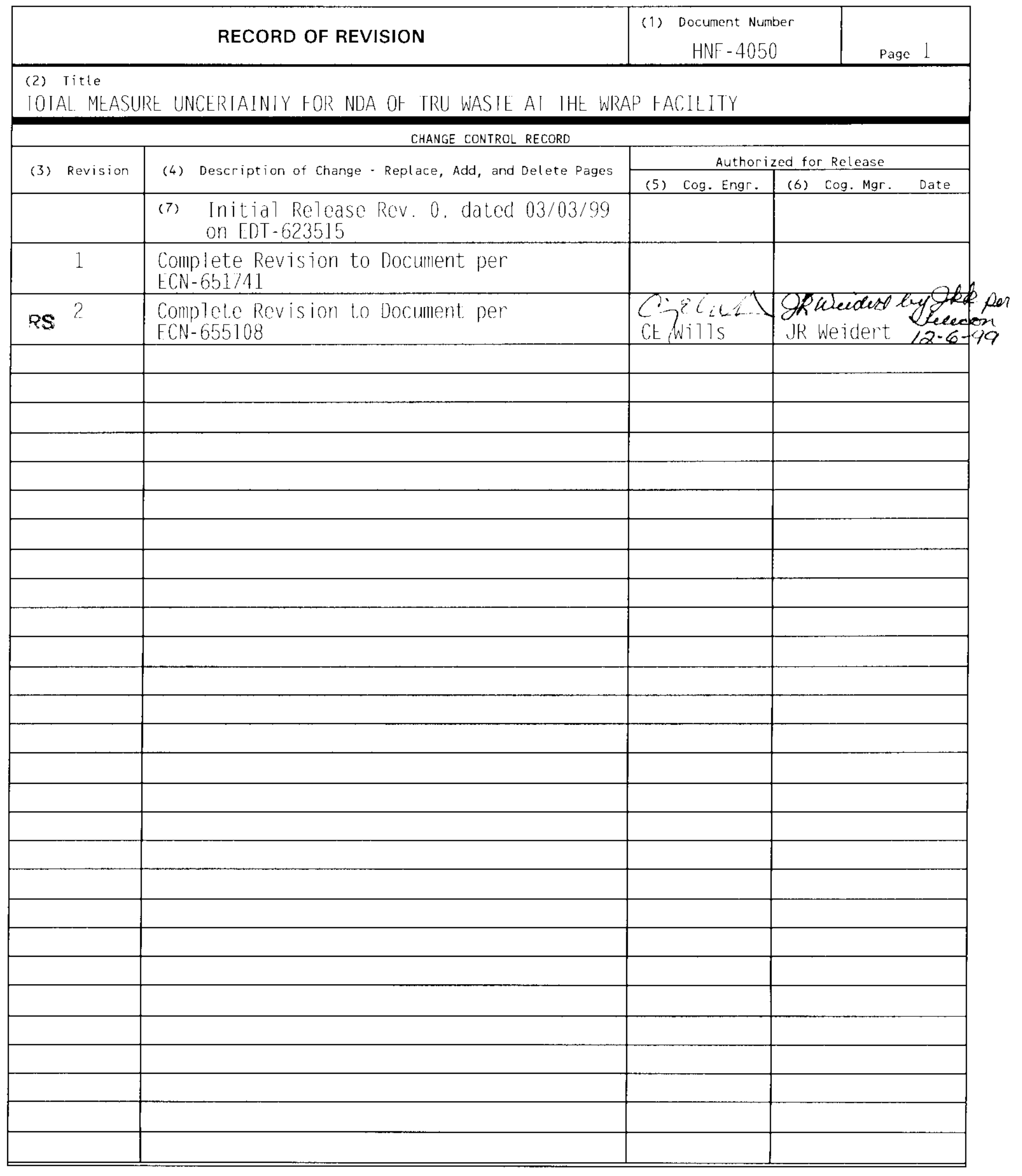


HNF-4050, Revision 2

\section{Total Measurement Uncertainty for Nondestructive Assay of Transuranic Waste at the Waste Receiving and Processing Facility}

Terri Welsh, Protection Technology Hanford Craig Wills, Fluor Daniel Hanford

Michael Purcell, Fluor Daniel Hanford 


\section{$\underline{\text { Executive Summary }}$}

The Waste Receiving and Processing (WRAP) facility, located on the Hanford Site in southeast Washington, is a key link in the certification of transuranic (TRU) waste for shipment to the Waste Isolation Pilot Plant (WIPP). Waste characterization is one of the vital functions performed at WRAP, and nondestructive assay (NDA) measurements of TRU waste containers is one of two required methods used for waste characterization. Various programs exist to ensure the validity of waste characterization data; all of these cite the need for clearly defined knowledge of the error, or uncertainty, associated with any measurements taken.

All measurements have an inherent uncertainty associated with them. The combined effect of all errors associated with a measurement is referred to as the total mcasurement uncertainty (TMU). NDA measurement uncertainties can be numerous and complex. In addition to system-induced measurement errors, there are other factors which contribute to the TMU associated with a particular measurement. NDA measurements at WRAP are based upon processes (radioactive decay and induced fission) which are statistical in nature. As a result, the proper statistical summation of the various error components is essential.

This report examines the contributing factors to NDA measurement uncertainty at WRAP. The significance of each factor on the TMU is analyzed, and a final method is given for determining the TMU for NDA measurements at WRAP. As more data becomes available, and WRAP gains in operational experience, this report will be reviewed semi-annually and updated as necessary. 


\section{Table of Contents}

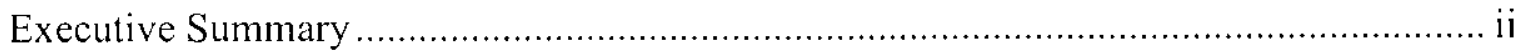

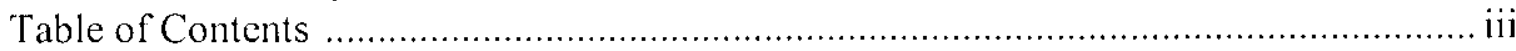

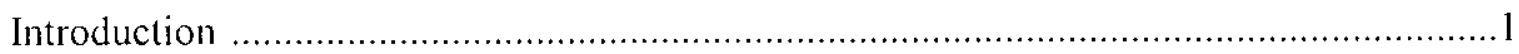

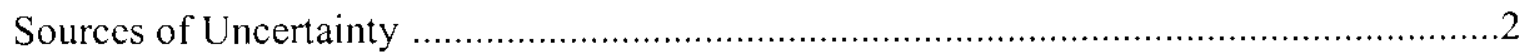

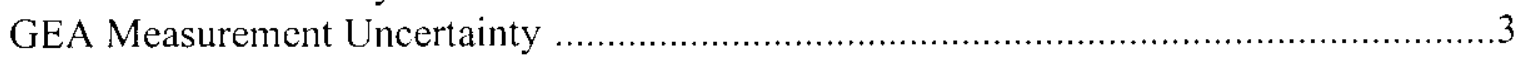

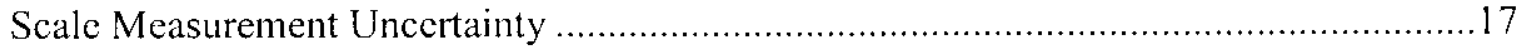

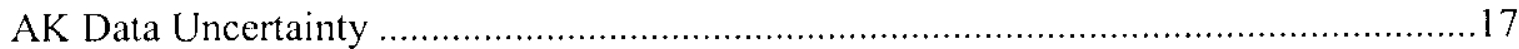

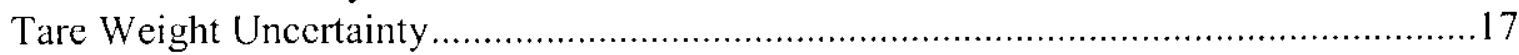

Other Measurement Uncertainties ….................................................................. 18

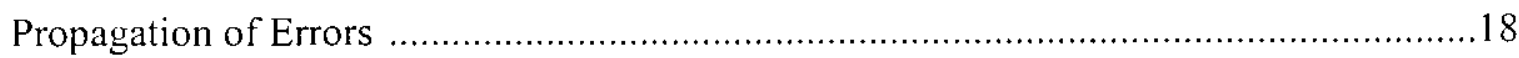

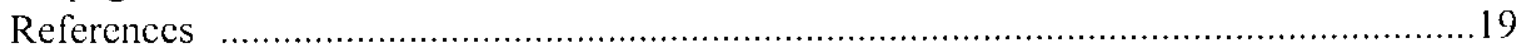


HNF 4050, Rev. 2

\section{$\underline{\text { Introduction }}$}

The process of performing NDA analysis on a waste container at WRAP invokes a number of other systems and processes. For purposes of this report, only waste drums shall be considered. All TRU or potentially TRU waste drums which enter the WRAP facility undergo the following process:

Acceptable knowledge (AK) data review and drum physical integrity check

Entry into the facility database for tracking

Temporary storage, as needed

Weight taken on facility scales and recorded for later use

Nondestructive examination (NDE)

NDA using Gamma Encrgy Assay (GEA) system

NDA analysis

Upon completion of this sequence, cach drum is assigned a waste class (TRU or low level). If the drum is TRU and contains no prohibited items for disposal at WIPP (determined through NDE), then all processing which could impact TMU is complete and final calculations are performed. Such drums are referred to as verification drums. If the drum is TRU and does contain prohibited items, it is dispositioned for processing in the WRAP TRU glovebox line, where it is opened for sorting and removal of the prohibited items. The contents are repackaged into a new drum, referred to as a process drum, which is considered newly generated waste. Upon release from the glovebox process area, each process drum is weighed and then subjected to NDE and NDA. All AK data associated with the contents of the original drum are maintained with the process drum. The TMU analysis within this document applies to verification and process drums equally.

As mentioned above, NDA is performed at WRAP using both ncutron and gamma assay techniques. There are two identical imaging passive/active neutron (IPAN) assayers and two identical gamma energy (GEA) assayers. Currently, only the GEA systems are used to characterize waste; therefore only the GEA systems are addressed in this document.

The WRAP GEA systems were built by Canberra Industries and use current versions of their Genie-PC and Gamma Waste Assay Software (GWAS) packages. The algorithms are welldocumented in the Canberra literature (Reference 2). The WRAP GEA is essentially what Canberra refers to as an IQ3 system, with a few unique features designed for the WRAP environment. The primary detectors are four vertically aligned, high-purity germanium detectors used for segmented gamma scanning. Directly opposite these detectors are four Eu-152 transmission sources which provide a measure of the matrix attenuation effects in each segment, across a wide range of energies. The drum platform moves to three vertical positions during an assay, thus dividing the drum into twelve segments for analysis. The uppermost and lowermost segments are discarded to eliminate end effects, leaving ten segments for analysis.

Transmission and density correction and "passive" gamma detection are performed on each 
segment, providing a well-defined picture of source distribution and matrix effects, while minimizing errors induced by same. A variety of reports are available to allow a complete and very detailed analysis of the waste. The GEA systems also have two germanium detectors designed for low energy (up to $300 \mathrm{kcV}$ ) gamma detection. These detectors collect the data used for the Multi-Group Analysis (MGA) software, which provides isotopic breakdown of plutonium and uranium waste.

NDA analysis uses data from a variety of sources: AK, WRAP scales, NDE, GEA, and, in the case of process drums, information glcancd from the sorting of the waste. Each data source has an associated uncertainty or set of uncertainties, which is the focus of this document. A detailed discussion of the analytical method used to synthesize these data is beyond the scope of this report. The general procedure can be found in WMH-350-2.2, "Calculation of Assay Results." Expert knowledge (NDA experience, system knowledge, etc) on the part of the NDA analyst is an invaluable component of the process.

\section{$\underline{\text { Sources of Uncertainty }}$}

Measurement uncertainty generally results from sources that may be divided into two categories: those which can be statistically evaluated, and those which cannot be statistically evaluated. The values for both types of uncertainty are combined to produce a final uncertainty value, or TMU. It is assumed that the statistical distribution of measurement errors within the waste stream population follows a normal distribution. It is also assumed that the individual error components are statistically independent. Another assumption is that the total bias is well approximated by a lincar function (Reference 4). For the TMU determination the uncertainty values for the different components will be combined using a "root sum of squares" method, as outlined in NIST Technical Note 1297.

Most sources of measurement uncertainty associated with NDA can be statistically evaluated. Such sources include scale readings and assay results. The statistical nature of radioactive decay or the interaction of a particle flux with a target matrix need not be belabored here, although these will be the dominant factors in analysis of NDA measurcment uncertainty. A simpler example is the amount of random fluctuation in weight scale readings, which can be estimated using statistical methods. The standard deviation of the mean of a scries of replicate measurements is used to evaluate this kind of measurement uncertainty. By convention, uncertainty values for a given measurement are expressed as a range, at a given confidence level (e.g., "At the $95 \%$ confidence level, the object weighs $53 \pm 2.7$ kilograms"). Uncertainties from sources which cannot be statistically evaluated are estimated; the contribution of these sources to the TMU can be quite large. Such sources include AK data and variations in drum and packaging material tare weights. The uncertainties - both statistical and estimated - associated with each of these sources are discussed below. 
HNF 4050, Rev. 2

\section{GEA MEASUREMENT UNCERTAINTY}

The primary components of the total measurement uncertainty in the WRAP GEA assay are:

Calibration source uncertainties

Counting statistics

Source self-absorption uncertainties (lumps)

Source nonuniformities

Matrix effects

Quality assurance measurements are obtained to ensure that the system is performing properly, within a pre-determined set of criteria, and that there are no immediate or long-term slow changes to the system operation. This is carried out by making two measurements, an assay of a known sample and a measurement of the background. The first measurement serves to determine if all of the detectors are functioning properly, while the second serves as a measure of whether there has been contamination of the system or changes in the area around the system. Additional details regarding QA measurements can be found in Reference 2.

\section{Calibration Source Uncertainties}

There are typically two components of the overall calibration uncertainty. The first is the uncertainty associated with the calibration sources; this is included in the source certificate files used to calibrate the instrument. The second is the uncertainty associated with the calibration counting statistics and fit of the calibration data to the calibration curve. This uncertainty, like the first, is automatically calculated and propagated in the GEA software so that measurement uncertainties will reflect the calibration uncertainty. Algorithms for propagation of the calibration source uncertainties are contained in Reference 2. For calibration of 208 liter drums, there is no additional calibration uncertainty beyond that generated by the GEA software.

\section{Counting Statistics Uncertainties (Random Error)}

Counting statistics uncertainties are very small when significant quantities of material are present but ultimately become the dominant source of uncertainty as the radioactive source strength decreases. The GEA software propagates this uncertainty term. The counting statistics tend to be the primary effect in the precision of the measurements. The algorithms for propagation of the counting statistics uncertainties are contained in Reference 2. 
The random error for the GEA assay system can be estimated from repeated measurements of representative waste drums. Various masses of weapons grade plutonium in the form of NIST traceable standards were placed in PDP matrices 001 (Empty) and 003 (Combustibles) and multiple measurements obtained. All measurements were performed under normal operating conditions in the WRAP facility, so uncertainty arising from local background variability is included in the estimates. Measurement times were the same as those used under normal operating conditions. The number of repeat measurements for each drum varied between 5 and 15. Since a large number ( $>100$ sets) of repcated measurements were carried out, only a representative sample of the results have been reported in Tables 1.A - 1.F. For comparison purposes, the counting statistics uncertainty as reported by the GEA system and used in the TMU determinations at WRAP is also listed. As can be seen in Table 1, the two uncertainty cstimates (\% RSD from multiple measurements and \% RSD from the instrument statistics) are close which validates the use of the uncertainty as generated by the software.

\section{Self Absorption Uncertainties}

Self absorption uncertainties depend on the quantity of plutonium in a "lump," lump density, and the waste material type. Self absorption errors are difficult to calculate except for the worst case measurement potentials. This would be represented by a spherical metallic source. Reference 1 reports a worst case underestimate for a Segmented Gamma Scan (SGS) assay of a single $1 \mathrm{gram}$ spherical lump of pure plutonium metal using the Pu-239 gamma-ray peak at $414 \mathrm{keV}$ at $25 \%$ assuming no differential peak correction is applied. The probability of having a single spherical lump of metal waste is highly unlikely. Therefore a more realistic assumption would be a single 1 gram lump of $\mathrm{PuO}_{2}$ which might be plated onto a pipe, crucible or other matrix form. It can be calculated that changing from a metal to an oxide and changing the geometry to a less spherical shape would reduce the self absorption underestimation to less than $5 \%$. Going through the same excrcise for a larger single 10-gram spherical lump, the attenuation would be approximately $70 \%$, again assuming no differential peak correction. Reconsidering this as a $\mathrm{PuO}_{2}$ rather than a metal and considering the material in a more plated form would greatly reduce the self absorption effects. Furthermore the probability of a single 10 -gram lump is much less probable than a number of smaller lumps summing to 10 grams (Reference 3 ).

The differential peak absorption correction, which is performed by the GEA software, applies a correction for the Pu result based on the increased absorption of the $129 \mathrm{kcV}$ line over the 414 $\mathrm{keV}$ line. Theoretically, the mass absorption coefficient ratios, which are used in the differential peak correction equation, may tend to overestimate the result by $5 \%$ for small lumps of $\mathrm{Pu}$, depending on where the lump is located. Similarly, for large single lumps of $\mathrm{Pu}(>10 \mathrm{~g})$ the correction may underestimate the effect of the lump depending on the location and distribution with other distributed plutonium. In fact, however, empirical data shows that the GEA software corrects for lumps quite effectively. For lumps of 5 grams or less, use of the Sum Segments algorithm provides a nominal value within $5 \%$ of the actual mass. This is well within the normal range of counting statistics, implying that no additional uncertainty is induced by small lumps. In 
tests simulating large lumps, the Combine All algorithm takes over. In the extreme case - a drum containing 310 grams of WG Pu - the nominal value was within $1 \%$ of the actual mass. This is representative of all cases simulating lumps; regardless of the lump size or arrangement being simulated, $\% \mathrm{R}$ is within the $95-105 \%$ range following bias correction (where applicable). Again, this is typically encompassed by counting statistics. The slight self-attenuation error is a small component of the catch-all " $\sigma$ other" error factor delineated in Table 3.

\section{Non-uniform Source Distribution Uncertainties}

The GEA software contains an algorithm which calculates non-uniformities in the distribution of source nuclides in the sample. The algorithm is described in Reference 2. The algorithm calculates a non-uniformity index for each segment for the transmission source energy and nuclide specificd. The software provides corrections to the activities measured for the cases of non-uniformity. Any uncertainty associated with source non-uniformity is incorporated in the " $\sigma$ other" error factor in Table 3.

\section{Matrix Effects}

Uncertainties due to matrix absorption are small for uniform matrices and source distributions. The GEA software corrects for this absorption by calculating the matrix density using the transmission correction technique. This technique measures the absorption of the gamma radiation for the matrix by beaming an extcrnal source through the drum with a gamma energy close to the energy of the primary assay peak. This directly accounts for both the density and the $Z$ effects of the matrix. Therefore the effects of the elemental composition of the matrix are dircctly accounted for in the correction technique. The algorithms and propagation of uncertainties are found in Reference 2.

Since the GEA assays the drum in small vertical segments, each of which reccives a transmission correction, the effect of waste matrix inhomogeneity is alleviated. This minimizes the potential uncertainty associated with stratified matrices of differing densities.

The uncertainty associated with a heterogeneous matrix distribution can be estimated using test drums. Various masses of weapons grade plutonium in the form of NIST traceable standards were placed in PDP matrices 001 (Empty) and 003 (Combustibles). The sources were placed at multiple radials (center, 6" from center, outside edge) and vertical positions (various inches as measured from the bottom of the drum) in the drum. It can be effectively argued that these test drums adequately simulate non-uniform matrices. A series of 9-inch long steel tubes dispersed at random throughout a drum void of most other materials is certainly non-uniform. Similarly, these same tubes dispersed throughout a matrix of low-density materials such as wood and plastic comprise a non-uniform matrix. The inclusion of random void spaces only heightens the effect. The simulation of source (as opposed to matrix) non-uniformity is obvious. The average 
uncertainty due to these effects seen over a wide range of test configurations is another component of the near-ubiquitous " $\sigma$ other."

\section{Bias}

The GEA data generated from the measurements of the Empty test drums containing the NIST traceable standards indicated that a bias exists in the measurements. The bias is associated with the configuration of the standards and the construction of the test drum. For cach QAO range (listed as I, II, III, or IV in Tables 2 and 3), data from the Empty test drum measurements were used to determine the applicable bias correction factor. All test drum results were then adjusted (dividing by the correction factor). The adjusted combustible test drum measurements indicated a bias in the measurements due to the combustibles matrix (see the "\%R Adj" column in Tables 1.A - 1.F). Matrix bias correction factors were determined from empirical data for each mass range and are listed in Table 2. The impact of these correction factors on final reported $\mathrm{Pu}$ mass is illustrated in Figures 1 and 2, based on the correction factors in Tables 1.B and 1.F, respectively.

Examination of the calibration curves shows that density correction is relatively linear up to $0.65 \mathrm{~g} / \mathrm{cm}^{3}$. Using this assumption, an equation was derived to determine a density-specific correction factor. With this equation, the generic factor in Table 2 is converted to a bias correction factor specific to each drum, and is applied to Pu masses accordingly. The equation is:

$$
\begin{aligned}
& \text { BCF } F_{x}=\left\{\left[\left(\rho_{x}-0.067\right) \times(B C F-1)\right] \div 0.212\right\}+1 \quad \text { (Equation 1) } \\
& \text { where } \mathrm{BCF}_{\mathrm{x}}=\text { the density/drum-specific correction factor, } \\
& \qquad \rho_{\mathrm{x}}=\text { the density of the drum under analysis, and } \\
& \mathrm{BCF}=\text { the generic bias correction factor from Table } 2 .
\end{aligned}
$$

Table 3 contains the uncertainty estimates associated with each bias correction factor and mass range (I-IV). 
HNF 4050, Rev. 2

Table 1.A. GEA A Combustibles Drum Test Results, Part I

\begin{tabular}{|c|c|c|c|c|c|c|c|}
\hline \multicolumn{8}{|c|}{ SUM SEGMENTS -- "Pu-239" (375 keV) } \\
\hline $\begin{array}{c}\text { WG Pu Mass } \\
\text { (g) }\end{array}$ & $\begin{array}{c}\text { Gross } \% \text { RSD } \\
\text { (Avg Runs) }\end{array}$ & $\begin{array}{c}\text { Min Ct Stat } \\
(\% \text { RSD })\end{array}$ & $\begin{array}{c}\text { Max Ct Stat } \\
(\% \mathrm{RSD})\end{array}$ & $\begin{array}{c}\text { Avg Ct Stat } \\
(\% \text { RSD })\end{array}$ & $\% \mathbf{R}$ & $\% \mathbf{R} \mathbf{A d j}$ & $\begin{array}{c}\text { Bias } \\
\text { Corrected }\end{array}$ \\
\hline $\begin{array}{l}0.06 \\
0.09 \\
0.09 \\
0.10 \\
0.15 \\
\end{array}$ & $\begin{array}{c}<\mathrm{MDC} \\
<\mathrm{MDC} \\
<\mathrm{MDC} \\
<\mathrm{MDC} \\
21.57\end{array}$ & $\begin{array}{c}<\mathrm{MDC} \\
<\mathrm{MDC} \\
<\mathrm{MDC} \\
<\mathrm{MDC} \\
14.76\end{array}$ & $\begin{array}{l}<\mathrm{MDC} \\
<\mathrm{MDC} \\
<\mathrm{MDC} \\
<\mathrm{MDC} \\
29.46\end{array}$ & $\begin{array}{c}<\mathrm{MDC} \\
<\mathrm{MDC} \\
<\mathrm{MDC} \\
<\mathrm{MDC} \\
22.52 \\
\end{array}$ & $\begin{array}{l}<\mathrm{MDC} \\
<\mathrm{MDC} \\
<\mathrm{MDC} \\
<\mathrm{MDC} \\
72.81\end{array}$ & N/A & $\mathrm{N} / \mathrm{A}$ \\
\hline $\begin{array}{l}0.33 \\
0.60 \\
0.60 \\
0.63 \\
0.66 \\
0.90 \\
0.90 \\
0.96 \\
0.99 \\
1.05 \\
1.20 \\
\end{array}$ & $\begin{array}{c}13.33 \\
5.35 \\
4.73 \\
5.78 \\
9.00 \\
9.51 \\
6.65 \\
7.24 \\
4.95 \\
2.75 \\
3.84 \\
\end{array}$ & $\begin{array}{l}10.30 \\
6.12 \\
5.79 \\
5.62 \\
5.79 \\
5.74 \\
4.54 \\
4.42 \\
4.20 \\
4.27 \\
3.38 \\
\end{array}$ & $\begin{array}{l}19.11 \\
8.69 \\
6.56 \\
7.97 \\
8.43 \\
7.57 \\
6.31 \\
6.10 \\
5.27 \\
5.60 \\
4.06 \\
\end{array}$ & $\begin{array}{c}12.95 \\
6.72 \\
6.12 \\
6.50 \\
6.62 \\
6.32 \\
5.47 \\
4.94 \\
4.82 \\
4.78 \\
3.58 \\
\end{array}$ & $\begin{array}{l}65.08 \\
79.47 \\
82.72 \\
78.63 \\
74.28 \\
71.44 \\
68.86 \\
74.53 \\
75.16 \\
74.33 \\
85.59 \\
\end{array}$ & $N / A$ & $N / A$ \\
\hline $\begin{array}{c}2.85 \\
3.15 \\
5.00 \\
5.00 \\
6.15 \\
7.53 \\
9.90 \\
9.90 \\
10.00 \\
12.20 \\
14.68 \\
17.70 \\
19.13 \\
23.88 \\
\end{array}$ & $\begin{array}{l}4.97 \\
3.84 \\
4.48 \\
5.63 \\
7.50 \\
2.49 \\
5.18 \\
0.86 \\
3.07 \\
1.75 \\
1.67 \\
3.78 \\
3.16 \\
1.01 \\
\end{array}$ & $\begin{array}{l}2.63 \\
2.72 \\
1.96 \\
2.09 \\
2.05 \\
1.88 \\
1.62 \\
1.68 \\
1.64 \\
1.61 \\
1.48 \\
1.47 \\
1.40 \\
1.31 \\
\end{array}$ & $\begin{array}{l}3.00 \\
3.11 \\
2.59 \\
2.54 \\
2.64 \\
2.16 \\
2.00 \\
3.11 \\
1.96 \\
1.77 \\
1.61 \\
1.69 \\
1.67 \\
1.43 \\
\end{array}$ & $\begin{array}{l}2.78 \\
2.89 \\
2.31 \\
2.21 \\
2.30 \\
1.97 \\
1.76 \\
1.72 \\
1.79 \\
1.69 \\
1.55 \\
1.54 \\
1.52 \\
1.38 \\
\end{array}$ & $\begin{array}{l}75.23 \\
62.86 \\
70.90 \\
77.40 \\
65.04 \\
74.77 \\
76.41 \\
77.84 \\
72.66 \\
76.20 \\
75.12 \\
72.36 \\
72.44 \\
68.44 \\
\end{array}$ & $\begin{array}{l}89.14 \\
74.49 \\
84.02 \\
91.71 \\
77.07 \\
88.59 \\
92.24 \\
90.54 \\
86.09 \\
90.29 \\
89.02 \\
85.74 \\
85.84 \\
81.10 \\
\end{array}$ & $\begin{array}{c}103.49 \\
86.48 \\
97.54 \\
106.48 \\
89.47 \\
102.85 \\
107.08 \\
105.12 \\
99.95 \\
104.83 \\
103.35 \\
99.54 \\
99.66 \\
94.16 \\
\end{array}$ \\
\hline $\begin{array}{c}28.60 \\
33.55 \\
39.00 \\
47.00 \\
54.30 \\
62.00 \\
68.67 \\
70.00 \\
92.25 \\
100.00 \\
102.70 \\
116.71 \\
135.70 \\
160.00 \\
\end{array}$ & $\begin{array}{l}2.68 \\
1.30 \\
1.33 \\
1.67 \\
2.29 \\
1.50 \\
3.35 \\
2.98 \\
2.09 \\
1.55 \\
1.89 \\
0.35 \\
2.59 \\
1.28 \\
\end{array}$ & $\begin{array}{l}1.25 \\
1.67 \\
1.14 \\
1.13 \\
1.09 \\
1.05 \\
1.34 \\
1.08 \\
1.25 \\
1.01 \\
0.99 \\
1.22 \\
1.18 \\
1.05\end{array}$ & $\begin{array}{l}1.44 \\
1.79 \\
1.27 \\
1.25 \\
1.23 \\
1.15 \\
1.55 \\
1.22 \\
1.39 \\
1.10 \\
1.05 \\
1.30 \\
1.37 \\
1.23\end{array}$ & $\begin{array}{l}1.34 \\
1.74 \\
1.23 \\
1.19 \\
1.16 \\
1.10 \\
1.47 \\
1.13 \\
1.32 \\
1.04 \\
1.03 \\
1.26 \\
1.27 \\
1.17\end{array}$ & $\begin{array}{l}67.95 \\
86.30 \\
70.62 \\
64.45 \\
71.84 \\
68.66 \\
82.40 \\
63.55 \\
79.10 \\
60.19 \\
63.04 \\
78.35 \\
77.04 \\
79.65 \\
\end{array}$ & $\begin{array}{l}92.24 \\
93.79 \\
95.86 \\
87.49 \\
97.52 \\
93.20 \\
89.54 \\
86.27 \\
85.96 \\
81.71 \\
85.58 \\
85.15 \\
83.73 \\
86.56\end{array}$ & $\begin{array}{c}103.76 \\
105.50 \\
107.83 \\
98.42 \\
109.70 \\
104.84 \\
100.72 \\
97.04 \\
96.69 \\
91.91 \\
96.26 \\
95.78 \\
94.18 \\
97.37\end{array}$ \\
\hline
\end{tabular}


INF 4050, Rev. 2

Table 1.B. GEA A Combustibles Drum Test Results, Part II

\begin{tabular}{|c|c|c|c|c|c|c|c|}
\hline \multicolumn{8}{|c|}{ SUM SEGMENTS -- "Pu-239A" (129 keV) } \\
\hline $\begin{array}{c}\text { WG Pu Mass } \\
\text { (g) }\end{array}$ & $\begin{array}{c}\text { Gross \%RSD } \\
\text { (Avg Runs) }\end{array}$ & $\begin{array}{c}\text { Min Ct Stat } \\
(\% \text { RSD })\end{array}$ & $\begin{array}{c}\text { Max Ct Stat } \\
(\% \mathrm{RSD})\end{array}$ & $\begin{array}{c}\text { Avg Ct Stat } \\
(\% \text { RSD })\end{array}$ & $\% R$ & $\% \mathrm{R} \mathrm{Adj}$ & $\begin{array}{c}\text { Bias } \\
\text { Corrected }\end{array}$ \\
\hline 0.06 & 18.46 & 13.28 & 33.14 & 20.76 & 113.26 & 118.59 & 111.46 \\
\hline 0.09 & 9.69 & 11.44 & 18.05 & 14.19 & 108.70 & 113.82 & 106.97 \\
\hline 0.09 & 10.50 & 13.72 & 22.80 & 16.51 & 94.44 & 98.89 & 92.94 \\
\hline 0.10 & 19.22 & 13.05 & $22.0 !$ & 17.22 & 88.08 & 92.23 & 86.68 \\
\hline 0.15 & 6.11 & 9.86 & 11.06 & 10.43 & 103.60 & 108.48 & 101.95 \\
\hline 0.33 & 5.95 & 5.62 & 8.61 & 6.75 & 99.47 & 101.69 & 94.50 \\
\hline 0.60 & 3.96 & 4.20 & 5.22 & 4.62 & 115.76 & 118.35 & 109.97 \\
\hline 0.60 & 2.87 & 4.41 & 5.04 & 4.80 & 113.56 & 116.10 & 107.88 \\
\hline 0.63 & 4.56 & 4.30 & 4.79 & 4.55 & 118.21 & 120.86 & 112.30 \\
\hline 0.66 & 3.84 & 4.23 & 5.05 & 4.68 & 108.49 & 110.92 & 103.07 \\
\hline 0.90 & 2.34 & 4.11 & 4.85 & 4.55 & 102.95 & 105.25 & 97.80 \\
\hline 0.90 & 2.40 & 4.30 & 4.96 & 4.64 & 91.46 & 93.51 & 86.89 \\
\hline 0.96 & 4.82 & 3.79 & 4.67 & 4.31 & 103.75 & 106.07 & 98.57 \\
\hline 0.99 & 4.56 & 3.82 & 4.71 & 4.23 & 103.85 & 106.17 & 98.66 \\
\hline 1.05 & 6.32 & 3.82 & 4.59 & 4.16 & 105.30 & 107.65 & 100.04 \\
\hline 1.20 & 5.49 & 3.54 & 3.67 & 3.60 & 95.08 & 97.21 & 90.33 \\
\hline 2.85 & 4.43 & 3.43 & 3.52 & 3.47 & 98.03 & 119.01 & 112.26 \\
\hline 3.15 & 4.47 & 3.36 & 3.67 & 3.52 & 79.10 & 96.02 & 90.58 \\
\hline 5.00 & 4.10 & 3.12 & 3.38 & 3.33 & 82.49 & 100.14 & 94.46 \\
\hline 5.00 & 4.99 & 3.24 & 3.38 & 3.26 & 99.27 & 120.51 & 113.68 \\
\hline 6.15 & 1.29 & 3.19 & 3.30 & 3.24 & 82.77 & 100.49 & 94.79 \\
\hline 7.53 & 3.43 & 3.13 & 3.18 & 3.16 & 93.30 & 113.27 & 106.84 \\
\hline 9.90 & 2.34 & 3.06 & 3.11 & 3.09 & 96.42 & 116.81 & 110.19 \\
\hline 9.90 & 0.75 & 3.07 & 3.67 & 3.09 & 96.22 & 117.06 & 110.42 \\
\hline 10.00 & 4.02 & 3.11 & 3.15 & 3.13 & 86.50 & 105.01 & 99.06 \\
\hline 12.20 & 5.14 & 3.13 & 3.13 & 3.13 & 93.80 & 113.88 & 107.42 \\
\hline 14.68 & 4.06 & 3.07 & 3.13 & 3.10 & 88.09 & 106.95 & 100.88 \\
\hline 17.70 & 2.82 & 3.04 & 3.06 & 3.05 & 80.69 & 97.96 & 92.41 \\
\hline 19.13 & 3.43 & 3.08 & 3.10 & 3.09 & 82.31 & 99.93 & 94.26 \\
\hline 23.88 & 3.64 & 3.09 & 3.11 & 3.10 & 63.54 & 77.13 & 72.76 \\
\hline 28.60 & $3.2 !$ & 3.02 & 3.04 & 3.03 & 67.76 & & \\
\hline 33.55 & 12.70 & 245.41 & 246.23 & 245.68 & 11.47 & & \\
\hline 39.00 & 3.02 & 3.03 & 3.05 & 3.04 & 70.98 & & \\
\hline 47.00 & 3.19 & 3.01 & 3.04 & 3.02 & 47.36 & & \\
\hline 54.30 & 3.10 & 3.02 & 3.04 & 3.03 & 67.84 & & \\
\hline 62.00 & 3.66 & 3.03 & 3.04 & 3.04 & 53.90 & & \\
\hline 68.67 & 7.96 & 245.15 & 246.48 & 245.63 & 9.40 & $\mathrm{~N} / \mathrm{A}$ & $\mathrm{N} / \mathrm{A}$ \\
\hline 70.00 & 2.62 & 2.98 & 2.99 & 2.99 & 56.64 & & \\
\hline 92.25 & 9.81 & 244.71 & 246.49 & 245.62 & 7.84 & & \\
\hline 100.00 & 2.28 & 2.98 & 2.99 & 2.98 & 45.91 & & \\
\hline 102.70 & 0.45 & 3.01 & 3.02 & 3.02 & 49.15 & & \\
\hline 116.71 & 8.83 & 244.90 & 246.24 & 245.55 & 8.16 & & \\
\hline 135.70 & 8.74 & 245.06 & 245.79 & 245.54 & 7.37 & & \\
\hline 160.00 & 8.26 & 251.66 & 252.84 & 252.22 & 8.13 & & \\
\hline
\end{tabular}


HNF 4050, Rev. 2

Table 1.C. GEA A Combustibles Drum Test Results, Part III

\begin{tabular}{|c|c|c|c|c|c|c|c|}
\hline \multicolumn{8}{|c|}{ SUM SEGMENTS -- "Pu-239B" (414 keV) } \\
\hline $\begin{array}{c}\text { WG Pu Mass } \\
\text { (g) }\end{array}$ & $\begin{array}{c}\text { Gross \%RSD } \\
\text { (Avg Runs) }\end{array}$ & $\begin{array}{c}\text { Min Ct Stat } \\
(\% \text { RSD })\end{array}$ & $\begin{array}{c}\text { Max Ct Stat } \\
(\% \text { RSD })\end{array}$ & $\begin{array}{c}\text { Avg Ct Stat } \\
(\% \text { RSD })\end{array}$ & $\% \mathbf{R}$ & $\% R$ Adj & $\begin{array}{c}\text { Bias } \\
\text { Corrected }\end{array}$ \\
\hline $\begin{array}{l}0.06 \\
0.09 \\
0.09 \\
0.10 \\
0.15 \\
\end{array}$ & $\begin{array}{c}<\mathrm{MDC} \\
<\mathrm{MDC} \\
<\mathrm{MDC} \\
<\mathrm{MDC} \\
16.35 \\
\end{array}$ & $\begin{array}{c}<\mathrm{MDC} \\
<\mathrm{MDC} \\
<\mathrm{MDC} \\
<\mathrm{MDC} \\
16.64\end{array}$ & $\begin{array}{c}<\mathrm{MDC} \\
<\mathrm{MDC} \\
<\mathrm{MDC} \\
<\mathrm{MDC} \\
39.89 \\
\end{array}$ & $\begin{array}{c}<\mathrm{MDC} \\
<\mathrm{MDC} \\
<\mathrm{MDC} \\
<\mathrm{MDC} \\
25.41\end{array}$ & $\begin{array}{l}<\mathrm{MDC} \\
<\mathrm{MDC} \\
<\mathrm{MDC} \\
<\mathrm{MDC} \\
81.39\end{array}$ & N/A & $\mathrm{N} / \mathrm{A}$ \\
\hline $\begin{array}{l}0.33 \\
0.60 \\
0.60 \\
0.63 \\
0.66 \\
0.90 \\
0.90 \\
0.96 \\
0.99 \\
1.05 \\
1.20\end{array}$ & $\begin{array}{c}6.02 \\
7.00 \\
10.62 \\
3.82 \\
6.53 \\
4.55 \\
5.63 \\
4.86 \\
5.33 \\
4.50 \\
1.44\end{array}$ & $\begin{array}{l}10.51 \\
6.44 \\
6.28 \\
6.19 \\
6.25 \\
6.23 \\
5.63 \\
5.51 \\
5.14 \\
4.77 \\
4.17\end{array}$ & $\begin{array}{c}18.60 \\
9.88 \\
8.36 \\
7.81 \\
7.58 \\
8.80 \\
7.01 \\
6.74 \\
6.39 \\
5.83 \\
4.53\end{array}$ & $\begin{array}{l}13.45 \\
7.74 \\
7.60 \\
7.06 \\
6.88 \\
7.53 \\
6.34 \\
6.20 \\
5.62 \\
5.47 \\
4.36\end{array}$ & $\begin{array}{l}71.53 \\
80.38 \\
81.69 \\
85.28 \\
81.97 \\
77.93 \\
72.79 \\
76.15 \\
78.31 \\
78.32 \\
91.03\end{array}$ & $\begin{array}{c}80.69 \\
90.67 \\
92.15 \\
96.21 \\
92.47 \\
87.92 \\
82.11 \\
85.91 \\
88.35 \\
88.35 \\
102.69\end{array}$ & $\begin{array}{c}89.88 \\
101.00 \\
102.65 \\
107.17 \\
103.01 \\
97.93 \\
91.46 \\
95.69 \\
98.41 \\
98.41 \\
114.39\end{array}$ \\
\hline $\begin{array}{l}2.85 \\
3.15 \\
5.00 \\
5.00 \\
6.15 \\
7.53 \\
9.90 \\
9.90 \\
10.00 \\
12.20 \\
14.68 \\
17.70 \\
19.13 \\
23.88\end{array}$ & $\begin{array}{l}2.3 ! \\
2.47 \\
2.17 \\
1.91 \\
2.15 \\
2.02 \\
1.74 \\
2.31 \\
1.58 \\
0.64 \\
1.72 \\
1.14 \\
0.53 \\
1.07\end{array}$ & $\begin{array}{l}3.44 \\
3.49 \\
2.82 \\
2.89 \\
2.82 \\
2.67 \\
2.53 \\
2.56 \\
2.57 \\
2.48 \\
2.45 \\
2.41 \\
2.38 \\
2.35\end{array}$ & $\begin{array}{l}3.62 \\
3.62 \\
3.02 \\
3.02 \\
2.90 \\
2.74 \\
2.59 \\
3.62 \\
2.62 \\
2.52 \\
2.48 \\
2.44 \\
2.42 \\
2.39\end{array}$ & $\begin{array}{l}3.53 \\
3.57 \\
2.98 \\
2.93 \\
2.86 \\
2.69 \\
2.57 \\
2.58 \\
2.59 \\
2.50 \\
2.47 \\
2.42 \\
2.40 \\
2.37\end{array}$ & $\begin{array}{l}77.21 \\
65.46 \\
72.26 \\
77.46 \\
70.05 \\
76.19 \\
76.87 \\
76.33 \\
72.51 \\
77.04 \\
74.07 \\
71.98 \\
72.56 \\
67.31\end{array}$ & $\begin{array}{l}91.18 \\
77.31 \\
85.33 \\
91.47 \\
82.72 \\
89.97 \\
90.13 \\
90.77 \\
85.62 \\
90.97 \\
87.46 \\
85.00 \\
85.69 \\
79.48\end{array}$ & $\begin{array}{c}105.23 \\
89.22 \\
98.48 \\
105.56 \\
95.46 \\
103.84 \\
104.02 \\
104.76 \\
98.81 \\
104.98 \\
100.94 \\
98.09 \\
98.89 \\
91.73\end{array}$ \\
\hline $\begin{array}{c}28.60 \\
33.55 \\
39.00 \\
47.00 \\
54.30 \\
62.00 \\
68.67 \\
70.00 \\
92.25 \\
100.00 \\
102.70 \\
116.71 \\
135.70 \\
160.00\end{array}$ & $\begin{array}{l}0.55 \\
0.60 \\
0.93 \\
0.71 \\
0.74 \\
0.42 \\
1.10 \\
0.56 \\
1.05 \\
0.66 \\
0.56 \\
0.58 \\
0.45 \\
0.62\end{array}$ & $\begin{array}{l}2.34 \\
2.45 \\
2.29 \\
2.28 \\
2.27 \\
2.26 \\
2.31 \\
2.25 \\
2.29 \\
2.24 \\
2.23 \\
2.25 \\
2.26 \\
2.25\end{array}$ & $\begin{array}{l}2.35 \\
2.49 \\
2.31 \\
2.30 \\
2.27 \\
2.26 \\
2.34 \\
2.27 \\
2.31 \\
2.25 \\
2.24 \\
2.28 \\
2.27 \\
2.27\end{array}$ & $\begin{array}{l}2.35 \\
2.47 \\
2.30 \\
2.29 \\
2.27 \\
2.26 \\
2.33 \\
2.26 \\
2.30 \\
2.24 \\
2.23 \\
2.27 \\
2.26 \\
2.26\end{array}$ & $\begin{array}{l}67.56 \\
87.65 \\
68.74 \\
62.87 \\
70.23 \\
66.89 \\
83.51 \\
62.00 \\
77.87 \\
57.66 \\
61.15 \\
77.09 \\
76.71 \\
77.75 \\
\end{array}$ & $\begin{array}{l}93.88 \\
97.72 \\
95.51 \\
87.36 \\
97.59 \\
92.94 \\
93.11 \\
86.15 \\
86.82 \\
80.12 \\
84.96 \\
85.95 \\
85.53 \\
86.69 \\
\end{array}$ & $\begin{array}{c}104.78 \\
109.07 \\
106.61 \\
97.50 \\
108.92 \\
103.73 \\
103.92 \\
96.16 \\
96.90 \\
89.43 \\
94.83 \\
95.93 \\
95.46 \\
96.76 \\
\end{array}$ \\
\hline
\end{tabular}


HNF 4050, Rev. 2

Table 1.D. GEA A Combustibles Drum Test Results, Part IV

\begin{tabular}{|c|c|c|c|c|c|c|c|}
\hline \multicolumn{8}{|c|}{ COMBINE ALL -- “Pu-239" (375 keV) } \\
\hline $\begin{array}{c}\text { WG Pu Mass } \\
\text { (g) }\end{array}$ & $\begin{array}{c}\text { Gross \% RSD } \\
\text { (Avg Runs) }\end{array}$ & $\begin{array}{c}\text { Min Ct Stat } \\
(\% \mathrm{RSD})\end{array}$ & $\begin{array}{c}\text { Max Ct Stat } \\
\text { (1\%RSD) }\end{array}$ & $\begin{array}{c}\text { Avg Ct Stat } \\
\text { (\%RSD) }\end{array}$ & $\% R$ & $\%$ R Adj & $\begin{array}{c}\text { Bias } \\
\text { Corrected }\end{array}$ \\
\hline $\begin{array}{l}0.06 \\
0.09 \\
0.09 \\
0.10 \\
0.15\end{array}$ & $\begin{array}{l}<\mathrm{MDC} \\
<\mathrm{MDC} \\
<\mathrm{MDC} \\
<\mathrm{MDC} \\
71.25\end{array}$ & $\begin{array}{c}<\mathrm{MDC} \\
<\mathrm{MDC} \\
<\mathrm{MDC} \\
<\mathrm{MDC} \\
14.76\end{array}$ & $\begin{array}{l}<\mathrm{MDC} \\
<\mathrm{MDC} \\
<\mathrm{MDC} \\
<\mathrm{MDC} \\
36.72\end{array}$ & $\begin{array}{l}<\mathrm{MDC} \\
<\mathrm{MDC} \\
<\mathrm{MDC} \\
<\mathrm{MDC} \\
27.75\end{array}$ & $\begin{array}{l}<\mathrm{MDC} \\
<\mathrm{MDC} \\
<\mathrm{MDC} \\
<\mathrm{MDC} \\
50.35\end{array}$ & $\mathrm{~N} / \mathrm{A}$ & N/A \\
\hline $\begin{array}{l}0.33 \\
0.60 \\
0.60 \\
0.63 \\
0.66 \\
0.90 \\
0.90 \\
0.96 \\
0.99 \\
1.05 \\
1.20 \\
\end{array}$ & $\begin{array}{c}29.45 \\
11.03 \\
14.09 \\
7.64 \\
12.12 \\
27.32 \\
17.49 \\
7.42 \\
16.27 \\
5.10 \\
4.78 \\
\end{array}$ & $\begin{array}{c}10.15 \\
6.91 \\
5.79 \\
5.83 \\
6.05 \\
6.42 \\
6.04 \\
4.88 \\
5.15 \\
4.75 \\
3.47 \\
\end{array}$ & $\begin{array}{c}27.10 \\
9.27 \\
7.55 \\
8.41 \\
9.21 \\
9.48 \\
8.44 \\
5.75 \\
7.95 \\
5.41 \\
4.25 \\
\end{array}$ & $\begin{array}{c}14.5 \mathrm{l} \\
7.64 \\
6.56 \\
6.66 \\
7.15 \\
7.66 \\
6.59 \\
5.47 \\
5.67 \\
5.06 \\
3.79 \\
\end{array}$ & $\begin{array}{l}47.60 \\
66.23 \\
71.23 \\
74.86 \\
73.87 \\
58.82 \\
69.24 \\
75.77 \\
73.80 \\
73.82 \\
84.67 \\
\end{array}$ & $\mathrm{~N} / \mathrm{A}$ & $\mathrm{N} / \mathrm{A}$ \\
\hline $\begin{array}{c}2.85 \\
3.15 \\
5.00 \\
5.00 \\
6.15 \\
7.53 \\
9.90 \\
9.90 \\
10.00 \\
12.20 \\
14.68 \\
17.70 \\
19.13 \\
23.88 \\
\end{array}$ & $\begin{array}{l}2.96 \\
2.77 \\
2.38 \\
3.12 \\
1.29 \\
1.33 \\
2.54 \\
3.08 \\
3.62 \\
3.06 \\
1.90 \\
1.90 \\
1.90 \\
2.32\end{array}$ & $\begin{array}{l}2.75 \\
2.83 \\
2.32 \\
2.20 \\
1.99 \\
2.04 \\
1.76 \\
1.76 \\
1.76 \\
1.67 \\
1.52 \\
1.60 \\
1.63 \\
1.61\end{array}$ & $\begin{array}{l}3.06 \\
3.05 \\
2.45 \\
2.34 \\
2.15 \\
2.17 \\
1.91 \\
3.05 \\
1.95 \\
1.75 \\
1.62 \\
1.69 \\
1.73 \\
1.68\end{array}$ & $\begin{array}{l}2.88 \\
2.95 \\
2.39 \\
2.26 \\
2.07 \\
2.10 \\
1.81 \\
1.81 \\
1.84 \\
1.72 \\
1.57 \\
1.63 \\
1.67 \\
1.64 \\
\end{array}$ & $\begin{array}{l}80.29 \\
72.37 \\
75.99 \\
81.41 \\
79.05 \\
78.18 \\
86.64 \\
86.03 \\
79.74 \\
82.22 \\
81.11 \\
82.08 \\
80.67 \\
74.05 \\
\end{array}$ & $\begin{array}{l}87.73 \\
79.08 \\
83.03 \\
88.96 \\
86.38 \\
85.43 \\
94.00 \\
94.67 \\
87.13 \\
89.84 \\
88.63 \\
89.69 \\
88.15 \\
80.92 \\
\end{array}$ & $\begin{array}{c}100.37 \\
90.48 \\
95.00 \\
101.78 \\
98.83 \\
97.74 \\
107.55 \\
108.32 \\
99.69 \\
102.79 \\
101.40 \\
102.62 \\
100.85 \\
92.58 \\
\end{array}$ \\
\hline $\begin{array}{c}28.60 \\
33.55 \\
39.00 \\
47.00 \\
54.30 \\
62.00 \\
68.67 \\
70.00 \\
92.25 \\
100.00 \\
102.70 \\
116.71 \\
135.70 \\
160.00\end{array}$ & $\begin{array}{l}1.99 \\
3.78 \\
1.69 \\
3.07 \\
1.46 \\
2.34 \\
2.62 \\
3.69 \\
1.80 \\
2.10 \\
1.27 \\
1.57 \\
3.29 \\
1.82\end{array}$ & $\begin{array}{l}1.48 \\
2.14 \\
1.38 \\
1.40 \\
1.35 \\
1.25 \\
1.86 \\
1.35 \\
1.72 \\
1.27 \\
1.21 \\
1.57 \\
1.55 \\
1.44\end{array}$ & $\begin{array}{l}1.56 \\
2.23 \\
1.42 \\
1.50 \\
1.40 \\
1.31 \\
1.96 \\
1.44 \\
1.79 \\
1.32 \\
1.25 \\
1.62 \\
1.74 \\
1.50\end{array}$ & $\begin{array}{l}1.52 \\
2.19 \\
1.40 \\
1.43 \\
1.37 \\
1.28 \\
1.90 \\
1.39 \\
1.74 \\
1.30 \\
1.23 \\
1.59 \\
1.63 \\
1.47\end{array}$ & $\begin{array}{l}77.63 \\
84.87 \\
78.59 \\
75.80 \\
77.25 \\
71.40 \\
81.49 \\
74.80 \\
74.75 \\
72.98 \\
77.24 \\
75.06 \\
73.25 \\
75.90\end{array}$ & $\begin{array}{l}88.67 \\
93.21 \\
89.76 \\
86.58 \\
88.24 \\
81.55 \\
89.50 \\
85.44 \\
82.09 \\
83.36 \\
88.22 \\
82.43 \\
80.45 \\
83.35\end{array}$ & $\begin{array}{c}103.21 \\
108.49 \\
104.48 \\
100.77 \\
102.70 \\
94.91 \\
104.17 \\
99.44 \\
95.55 \\
97.02 \\
102.68 \\
95.94 \\
93.64 \\
97.01\end{array}$ \\
\hline
\end{tabular}


HNF 4050, Rev. 2

Table 1.E. GEA A Combustibles Drum Test Results, Part V

\begin{tabular}{|c|c|c|c|c|c|c|c|}
\hline \multicolumn{8}{|c|}{ COMBINE AII -- "Pu-239A" (129 keV) } \\
\hline $\begin{array}{c}\text { WG Pu Mass } \\
\text { (g) }\end{array}$ & $\begin{array}{c}\text { Gross \%RSD } \\
\text { (Avg Runs) }\end{array}$ & $\begin{array}{l}\text { Min Ct Stat } \\
(\% \text { RSD })\end{array}$ & $\begin{array}{c}\text { Max Ct Stat } \\
\text { (\%RSD) }\end{array}$ & $\begin{array}{c}\text { Avg Ct Stat } \\
(\% \mathrm{RSD})\end{array}$ & $\% \mathbf{R}$ & $\%$ R Adj & $\begin{array}{c}\text { Bias } \\
\text { Corrected }\end{array}$ \\
\hline $\begin{array}{l}0.06 \\
0.09 \\
0.09 \\
0.10 \\
0.15 \\
\end{array}$ & $\begin{array}{c}92.15 \\
134.74 \\
95.95 \\
33.41 \\
23.34 \\
\end{array}$ & $\begin{array}{l}13.28 \\
13.15 \\
15.68 \\
12.51 \\
10.10 \\
\end{array}$ & $\begin{array}{l}47.58 \\
54.20 \\
59.58 \\
26.93 \\
14.32 \\
\end{array}$ & $\begin{array}{l}28.75 \\
31.32 \\
28.31 \\
17.40 \\
11.68 \\
\end{array}$ & $\begin{array}{l}38.91 \\
23.97 \\
40.04 \\
37.70 \\
57.02 \\
\end{array}$ & $N / A$ & $\mathrm{~N} / \mathrm{A}$ \\
\hline $\begin{array}{l}0.33 \\
0.60 \\
0.60 \\
0.63 \\
0.66 \\
0.90 \\
0.90 \\
0.96 \\
0.99 \\
1.05 \\
1.20 \\
\end{array}$ & $\begin{array}{l}5.57 \\
3.27 \\
2.76 \\
3.83 \\
3.76 \\
8.67 \\
1.64 \\
3.01 \\
6.49 \\
2.10 \\
2.70 \\
\end{array}$ & $\begin{array}{l}7.28 \\
5.18 \\
5.96 \\
5.39 \\
5.03 \\
4.68 \\
4.77 \\
4.86 \\
4.70 \\
5.14 \\
4.72 \\
\end{array}$ & $\begin{array}{l}8.38 \\
5.49 \\
6.26 \\
5.68 \\
5.39 \\
5.40 \\
4.90 \\
5.01 \\
5.45 \\
5.36 \\
4.82 \\
\end{array}$ & $\begin{array}{l}7.73 \\
5.35 \\
6.09 \\
5.53 \\
5.18 \\
4.99 \\
4.85 \\
4.92 \\
4.86 \\
5.24 \\
4.75 \\
\end{array}$ & $\begin{array}{l}60.09 \\
69.00 \\
66.85 \\
73.68 \\
77.90 \\
68.46 \\
72.54 \\
76.06 \\
76.40 \\
84.77 \\
97.72 \\
\end{array}$ & $\begin{array}{c}71.30 \\
81.87 \\
79.32 \\
87.42 \\
92.42 \\
81.22 \\
86.06 \\
90.25 \\
90.65 \\
100.58 \\
115.94 \\
\end{array}$ & $\begin{array}{c}80.27 \\
92.17 \\
89.31 \\
98.42 \\
104.06 \\
91.44 \\
96.89 \\
101.61 \\
102.06 \\
113.24 \\
130.53 \\
\end{array}$ \\
\hline $\begin{array}{c}2.85 \\
3.15 \\
5.00 \\
5.00 \\
6.15 \\
7.53 \\
9.90 \\
9.90 \\
10.00 \\
12.20 \\
14.68 \\
17.70 \\
19.13 \\
23.88\end{array}$ & $\begin{array}{l}1.81 \\
2.18 \\
1.55 \\
1.54 \\
0.93 \\
2.52 \\
2.03 \\
3.06 \\
2.25 \\
1.40 \\
1.44 \\
1.88 \\
2.90 \\
3.39\end{array}$ & $\begin{array}{l}4.70 \\
5.38 \\
4.98 \\
4.55 \\
3.70 \\
4.75 \\
4.16 \\
4.18 \\
4.04 \\
4.03 \\
3.63 \\
4.22 \\
4.27 \\
4.43\end{array}$ & $\begin{array}{l}4.82 \\
5.53 \\
5.12 \\
4.60 \\
3.72 \\
4.80 \\
4.23 \\
5.53 \\
4.13 \\
4.05 \\
3.66 \\
4.34 \\
4.41 \\
4.53\end{array}$ & $\begin{array}{l}4.76 \\
5.45 \\
5.05 \\
4.58 \\
3.71 \\
4.78 \\
4.19 \\
4.20 \\
4.08 \\
4.04 \\
3.64 \\
4.27 \\
4.32 \\
4.49\end{array}$ & $\begin{array}{l}76.02 \\
67.53 \\
60.96 \\
71.58 \\
72.11 \\
64.34 \\
81.37 \\
82.72 \\
69.82 \\
69.37 \\
69.49 \\
67.30 \\
69.21 \\
54.81\end{array}$ & $\begin{array}{l}87.80 \\
77.99 \\
70.40 \\
82.67 \\
83.28 \\
74.30 \\
95.53 \\
93.97 \\
80.63 \\
80.12 \\
80.25 \\
77.73 \\
79.93 \\
63.29\end{array}$ & $\begin{array}{c}108.98 \\
96.80 \\
87.39 \\
102.61 \\
103.38 \\
92.23 \\
118.58 \\
116.64 \\
100.09 \\
99.44 \\
99.61 \\
96.48 \\
99.21 \\
78.56\end{array}$ \\
\hline $\begin{array}{c}28.60 \\
33.55 \\
39.00 \\
47.00 \\
54.30 \\
62.00 \\
68.67 \\
70.00 \\
92.25 \\
100.00 \\
102.70 \\
116.71 \\
135.70 \\
160.00 \\
\end{array}$ & $\begin{array}{l}1.00 \\
9.19 \\
4.24 \\
2.39 \\
2.84 \\
1.72 \\
3.22 \\
2.67 \\
7.66 \\
5.96 \\
2.84 \\
3.47 \\
4.43 \\
6.13 \\
\end{array}$ & $\begin{array}{c}4.22 \\
70.50 \\
4.08 \\
4.12 \\
4.03 \\
3.88 \\
65.42 \\
4.32 \\
46.66 \\
3.80 \\
3.77 \\
45.03 \\
41.78 \\
45.74 \\
\end{array}$ & $\begin{array}{c}4.25 \\
77.07 \\
4.15 \\
4.21 \\
4.10 \\
3.97 \\
70.09 \\
4.40 \\
55.50 \\
4.07 \\
3.83 \\
51.57 \\
47.24 \\
52.82 \\
\end{array}$ & $\begin{array}{c}4.23 \\
74.47 \\
4.12 \\
4.17 \\
4.07 \\
3.93 \\
68.79 \\
4.36 \\
50.80 \\
3.88 \\
3.80 \\
47.37 \\
44.25 \\
49.62 \\
\end{array}$ & $\begin{array}{l}61.24 \\
20.19 \\
64.25 \\
46.93 \\
63.36 \\
41.14 \\
16.71 \\
55.29 \\
15.46 \\
47.40 \\
55.37 \\
15.48 \\
14.45 \\
14.89 \\
\end{array}$ & N/A & N/A \\
\hline
\end{tabular}


HNF 4050, Rev. 2

Table 1.F. GEA A Combustibles Drum Test Results, Part VI

\begin{tabular}{|c|c|c|c|c|c|c|c|}
\hline \multicolumn{8}{|c|}{ COMBINE ALL -- "Pu-239B" (414 keV) } \\
\hline $\begin{array}{l}\text { WG Pu Mass } \\
\text { (g) }\end{array}$ & $\begin{array}{c}\text { Gross "\%RSD } \\
\text { (Avg Runs) }\end{array}$ & $\begin{array}{c}\text { Min Ct Stat } \\
(\% \text { RSD) }\end{array}$ & $\begin{array}{c}\text { Max Ct Stat } \\
(\% \text { RSD })\end{array}$ & $\begin{array}{c}\text { Avg Ct Stat } \\
(\% \text { RSD })\end{array}$ & $\% \mathbf{R}$ & $\% R A d j$ & $\begin{array}{c}\text { Bias } \\
\text { Corrected }\end{array}$ \\
\hline $\begin{array}{l}0.06 \\
0.09 \\
0.09 \\
0.10 \\
0.15 \\
\end{array}$ & $\begin{array}{c}\mathrm{MDC} \\
<\mathrm{MDC} \\
<\mathrm{MDC} \\
<\mathrm{MDC} \\
84.47 \\
\end{array}$ & $\begin{array}{c}<\mathrm{MDC} \\
<\mathrm{MDC} \\
<\mathrm{MDC} \\
<\mathrm{MDC} \\
19.71\end{array}$ & $\begin{array}{c}<\mathrm{MDC} \\
<\mathrm{MDC} \\
<\mathrm{MDC} \\
<\mathrm{MDC} \\
40.68 \\
\end{array}$ & $\begin{array}{c}<\mathrm{MDC} \\
<\mathrm{MDC} \\
<\mathrm{MDC} \\
<\mathrm{MDC} \\
30.58 \\
\end{array}$ & $\begin{array}{l}<\mathrm{MDC} \\
<\mathrm{MDC} \\
<\mathrm{MDC} \\
<\mathrm{MDC} \\
44.05\end{array}$ & $\mathrm{~N} / \mathrm{A}$ & N/A \\
\hline $\begin{array}{l}0.33 \\
0.60 \\
0.60 \\
0.63 \\
0.66 \\
0.90 \\
0.90 \\
0.90 \\
0.99 \\
1.05 \\
1.20 \\
\end{array}$ & $\begin{array}{c}30.71 \\
11.66 \\
14.20 \\
6.89 \\
8.81 \\
25.83 \\
7.85 \\
8.49 \\
9.27 \\
4.10 \\
1.00 \\
\end{array}$ & $\begin{array}{l}9.86 \\
6.59 \\
6.27 \\
6.06 \\
6.35 \\
6.49 \\
5.71 \\
5.15 \\
5.03 \\
5.04 \\
4.03 \\
\end{array}$ & $\begin{array}{c}20.38 \\
8.32 \\
7.75 \\
7.09 \\
8.09 \\
9.21 \\
6.42 \\
6.02 \\
5.99 \\
5.39 \\
4.36 \\
\end{array}$ & $\begin{array}{l}13.13 \\
7.48 \\
7.18 \\
6.69 \\
7.03 \\
7.66 \\
6.13 \\
5.62 \\
5.39 \\
5.26 \\
4.16 \\
\end{array}$ & $\begin{array}{l}54.36 \\
69.45 \\
68.60 \\
78.92 \\
78.27 \\
58.16 \\
73.79 \\
80.42 \\
81.09 \\
83.64 \\
95.41 \\
\end{array}$ & $\begin{array}{c}67.17 \\
85.82 \\
84.76 \\
97.51 \\
96.72 \\
71.86 \\
91.18 \\
99.37 \\
100.20 \\
103.35 \\
117.89 \\
\end{array}$ & $\begin{array}{c}72.73 \\
92.93 \\
91.78 \\
105.59 \\
104.73 \\
77.82 \\
98.73 \\
107.60 \\
108.50 \\
111.91 \\
127.66 \\
\end{array}$ \\
\hline $\begin{array}{l}2.85 \\
3.15 \\
5.00 \\
5.00 \\
6.15 \\
7.53 \\
9.90 \\
9.90 \\
10.00 \\
12.20 \\
14.68 \\
17.70 \\
19.13 \\
23.88 \\
\end{array}$ & $\begin{array}{l}2.12 \\
3.28 \\
2.02 \\
2.69 \\
1.59 \\
2.12 \\
1.67 \\
2.31 \\
1.60 \\
0.52 \\
1.61 \\
0.93 \\
0.93 \\
0.79 \\
\end{array}$ & $\begin{array}{l}3.40 \\
3.61 \\
3.06 \\
2.83 \\
2.46 \\
2.76 \\
2.39 \\
2.40 \\
2.36 \\
2.28 \\
2.07 \\
2.30 \\
2.34 \\
2.38 \\
\end{array}$ & $\begin{array}{l}3.50 \\
3.82 \\
3.14 \\
2.91 \\
2.49 \\
2.81 \\
2.44 \\
3.82 \\
2.41 \\
2.31 \\
2.11 \\
2.33 \\
2.36 \\
2.41 \\
\end{array}$ & $\begin{array}{l}3.44 \\
3.67 \\
3.09 \\
2.87 \\
2.48 \\
2.78 \\
2.41 \\
2.42 \\
2.38 \\
2.29 \\
2.09 \\
2.32 \\
2.36 \\
2.39 \\
\end{array}$ & $\begin{array}{l}85.74 \\
76.50 \\
79.83 \\
85.71 \\
86.17 \\
83.66 \\
92.22 \\
91.65 \\
85.55 \\
88.20 \\
86.98 \\
85.89 \\
85.87 \\
80.20 \\
\end{array}$ & $\begin{array}{l}89.56 \\
79.91 \\
83.39 \\
89.53 \\
90.01 \\
87.39 \\
95.74 \\
96.33 \\
89.36 \\
92.13 \\
90.86 \\
89.73 \\
89.70 \\
83.78 \\
\end{array}$ & $\begin{array}{c}100.52 \\
89.68 \\
93.59 \\
100.48 \\
101.02 \\
98.08 \\
107.45 \\
108.12 \\
100.29 \\
103.40 \\
101.97 \\
100.70 \\
100.67 \\
94.03 \\
\end{array}$ \\
\hline $\begin{array}{c}28.60 \\
33.55 \\
39.00 \\
47.00 \\
54.30 \\
62.00 \\
68.67 \\
70.00 \\
92.25 \\
100.00 \\
102.70 \\
116.71 \\
135.70 \\
160.00\end{array}$ & $\begin{array}{l}0.29 \\
0.43 \\
1.39 \\
0.84 \\
0.72 \\
0.42 \\
1.21 \\
0.57 \\
1.40 \\
0.94 \\
0.62 \\
0.69 \\
1.35 \\
1.03\end{array}$ & $\begin{array}{l}2.21 \\
3.33 \\
2.12 \\
2.19 \\
2.06 \\
1.97 \\
3.05 \\
2.17 \\
2.78 \\
2.04 \\
1.94 \\
2.52 \\
2.58 \\
2.41\end{array}$ & $\begin{array}{l}2.23 \\
3.40 \\
2.13 \\
2.21 \\
2.09 \\
1.98 \\
3.11 \\
2.19 \\
2.82 \\
2.06 \\
1.95 \\
2.54 \\
2.62 \\
2.44\end{array}$ & $\begin{array}{l}2.22 \\
3.37 \\
2.12 \\
2.20 \\
2.08 \\
1.98 \\
3.07 \\
2.18 \\
2.79 \\
2.05 \\
1.95 \\
2.53 \\
2.61 \\
2.42\end{array}$ & $\begin{array}{l}82.87 \\
89.33 \\
82.50 \\
81.60 \\
83.60 \\
76.04 \\
86.96 \\
81.73 \\
80.11 \\
78.18 \\
82.82 \\
81.49 \\
79.98 \\
81.22\end{array}$ & $\begin{array}{l}89.71 \\
93.60 \\
89.31 \\
88.34 \\
90.51 \\
82.32 \\
91.11 \\
88.48 \\
83.93 \\
84.64 \\
89.66 \\
85.39 \\
83.80 \\
85.10\end{array}$ & $\begin{array}{c}102.45 \\
106.89 \\
102.00 \\
100.88 \\
103.36 \\
94.02 \\
104.05 \\
101.04 \\
95.85 \\
96.66 \\
102.39 \\
97.51 \\
95.70 \\
97.19\end{array}$ \\
\hline
\end{tabular}


HNF 4050, Rev. 2

Figure 1

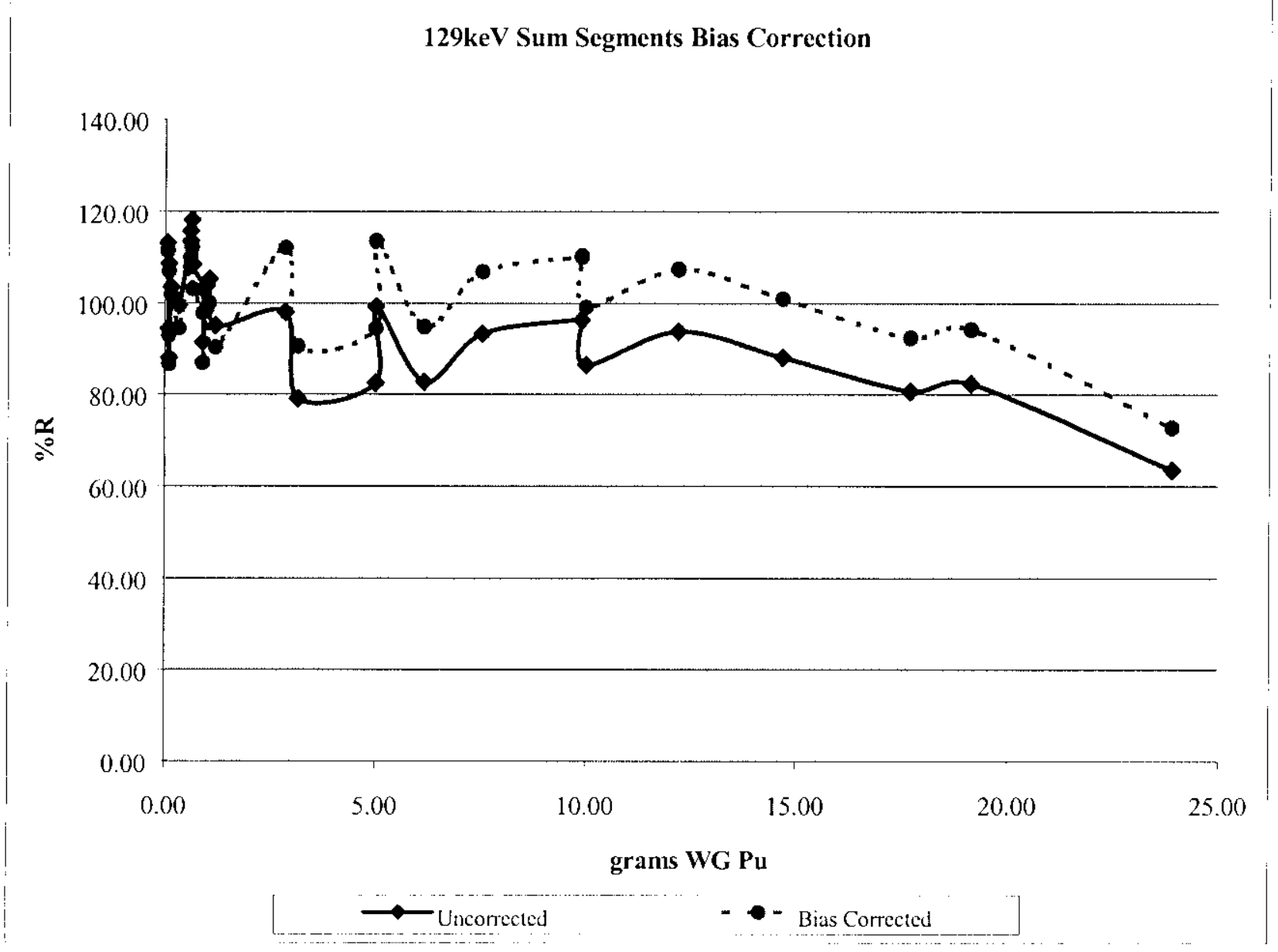

Note: This is typically used at 5 grams Pu and below, where the correction centers around 100\% 
HNF 4050, Rev. 2

Figure 2

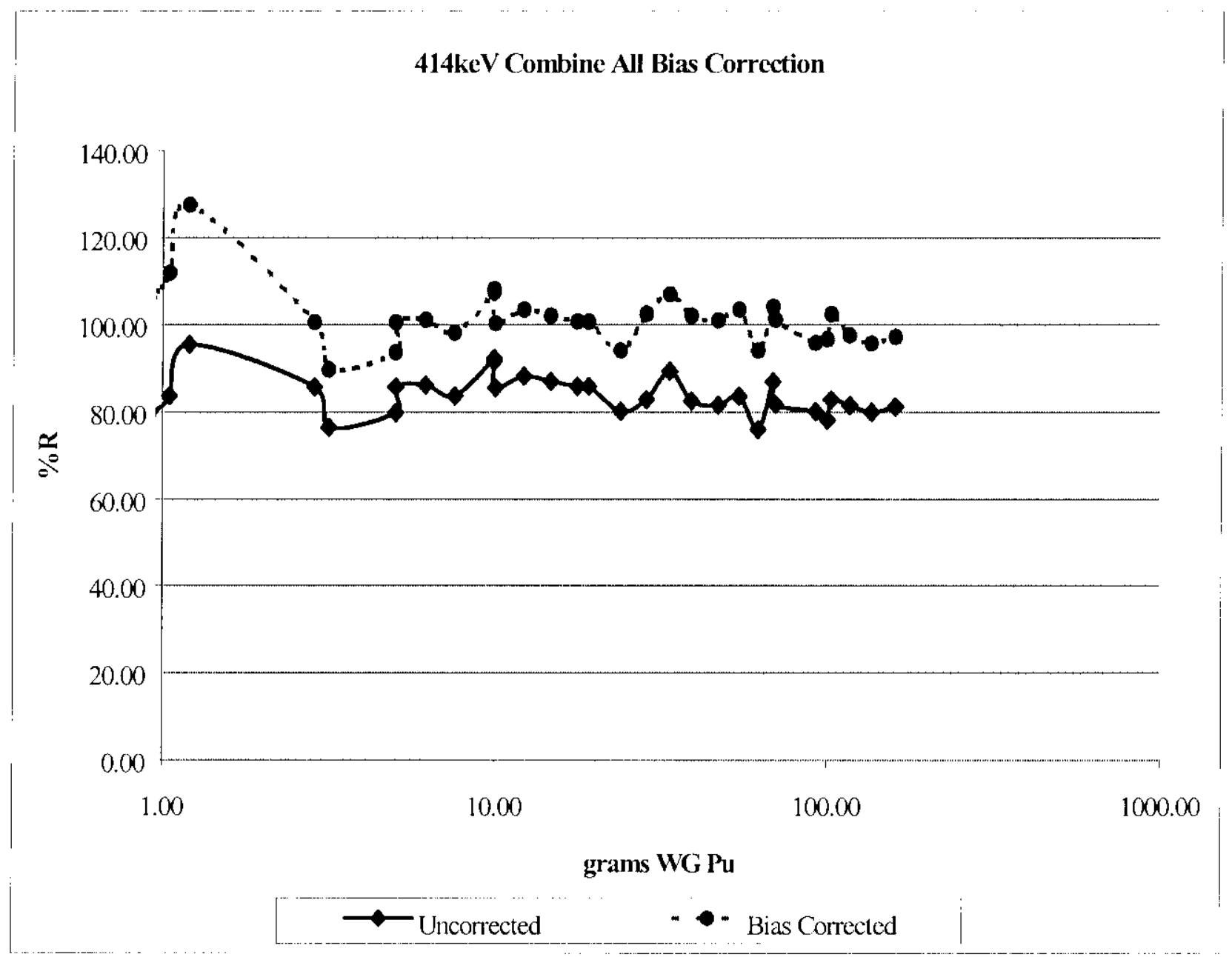

Note: This is typically used at 5 grams $\mathrm{Pu}$ and above, where the correction centers around $100 \%$ 
Table 2

\begin{tabular}{|c|c|c|c|c|c|c|}
\hline \multirow{3}{*}{$\begin{array}{l}\text { Mass } \\
\text { Range }\end{array}$} & \multicolumn{6}{|c|}{ Combustible Drum Bias Correction Factors (\%) } \\
\hline & \multicolumn{3}{|c|}{ Sum Segments } & \multicolumn{3}{|c|}{ Combine All } \\
\hline & $375 \mathrm{keV}$ & $129 \mathrm{keV}$ & $414 \mathrm{keV}$ & $375 \mathrm{keV}$ & $129 \mathrm{keV}$ & $414 \mathrm{keV}$ \\
\hline I & & 106.40 & & & & \\
\hline II & & 107.62 & 89.78 & & 88.82 & 92.35 \\
\hline III & 86.14 & 106.01 & 86.65 & 87.40 & 80.56 & 89.10 \\
\hline IV & $88 . \overline{90}$ & & 89.60 & 85.92 & & 87.56 \\
\hline
\end{tabular}

Notes

I, II, III, \& IV refer to the QAO mass ranges, where I is less than $0.25 \mathrm{~g} \mathrm{WG} \mathrm{Pu,} \mathrm{etc.}$

The $375 \mathrm{keV}, 129 \mathrm{keV}$, and $414 \mathrm{keV}$ headings refer to $\mathrm{Pu}-239$ energy peaks; these correspond to "Pu-239," "Pu-239A," and "Pu-239B," respectively, on the GEA report.

A shaded area indicates that the energy line in question is not used in that particular mass range. 
HNF 4050, Rev. 2

Table 3

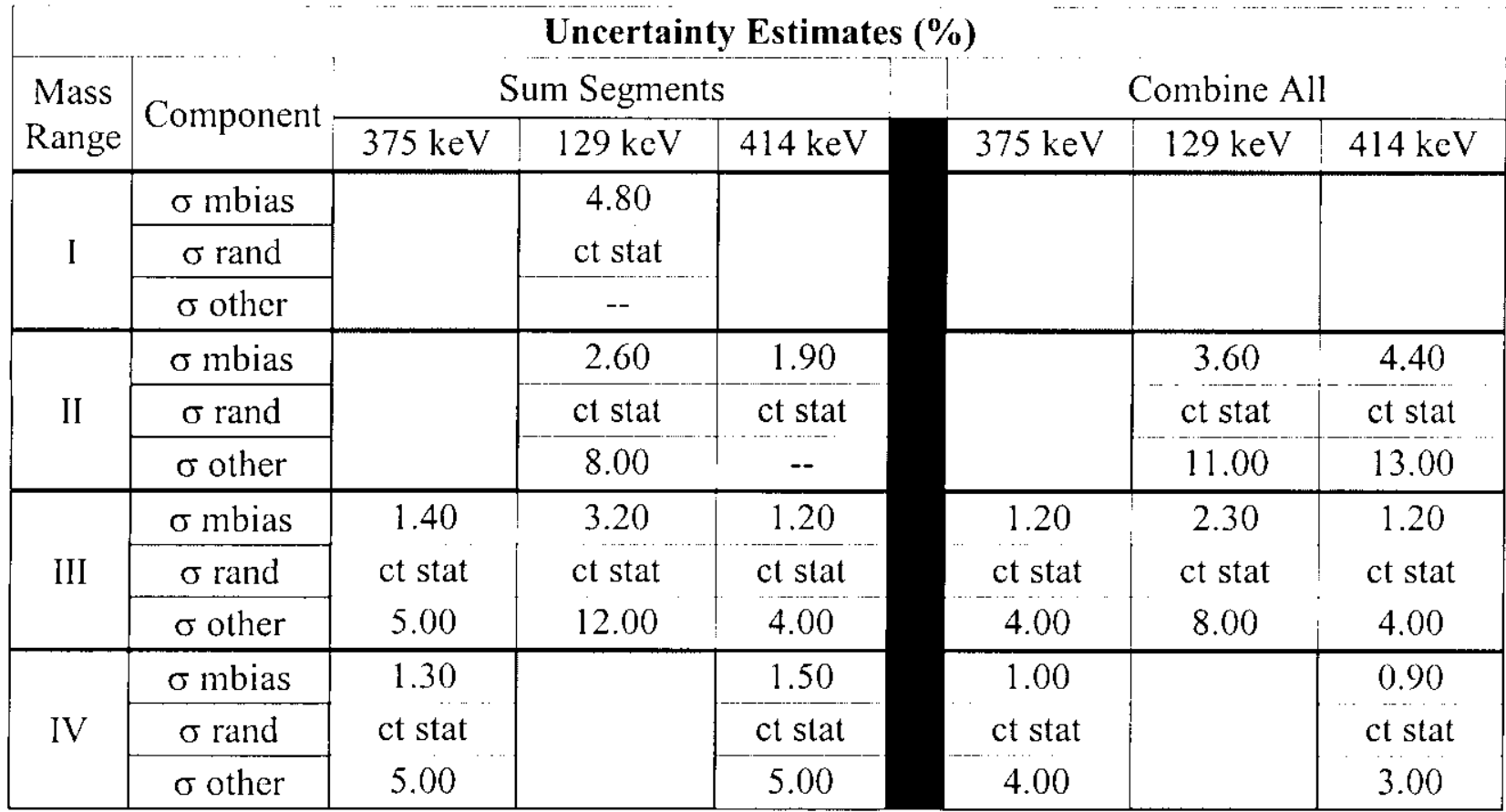

Notes

$\sigma$ mbias $\quad-$ the error associated with the bias correction for the matrix

$\sigma$ rand $\quad$-- the system-reported measurement error (i.c., counting statistics)

$\sigma$ other -- the crror due to source and matrix heterogeneity effects

"--" indicates an insignificant error level; no error is assigned in these cases

All errors ( $\sigma$ mbias, $\sigma$ rand, $\sigma$ other, weight uncertainty, isotopics/AK uncertainty) are summed in quadrature after all data is gathered and final calculations are prepared.

If possible, Sum Segments should be used for masses below $5 \mathrm{~g}$. For masses in the $0 \mathbf{- 2 . 5} \mathrm{g}$ range, the $129 \mathrm{keV}$ line is preferred. For all masses above $2.5 \mathrm{~g}$, the $414 \mathrm{keV}$ line should be used. The 375 line is used for reference and to indicate severe lumping. 


\section{Scale Measurement Uncertainty}

For a complete discussion of the uncertainty associated with scale measurements at WRAP, refer to HNF-3954, Drum Weight Measurement Uncertainty Review Findings (Reference 5). Engineering notebook WHC-N-930-2, page 97, calculates that the scale error at WRAP, determined through a simple standard deviation model based on calibration measurements, is $1.1549 \mathrm{lbs}(0.5239 \mathrm{~kg})$ at the $95 \%$ confidence level (1.96 sigma). Since errors are introduced and propagated at 1 sigma, and corrected to the $95 \%$ confidence level after all crrors are accounted for, this crror is introduced to calculations at $+/-0.5892 \mathrm{lbs}(0.2673 \mathrm{~kg})$.

\section{AK Data Uncertainty}

AK data, although an essential part of waste characterization, can easily be the source of the largest uncertainty associated with NDA analysis. This is due to the nature of AK, which is often gathered through a compilation of decades-old records, "process knowledge," and interviews with workers. Process knowledge and intervicws are entirely subjective in nature, and past records are often suspect since the regulatory scrutiny encountered today did not exist when the records were generated. In rare cases, such as the Plutonium Finishing Plant (PFP) at Hanford, process knowledge of one (or more) data component is so precise that the accompanying error is negligible. At PFP, which is projected to be the source of WRAP's initial TRU waste stream, the operational and criticality requirements have been so rigorous that plutonium isotopic knowledge is accurate to at least four significant digits. This is far more accurate than the MGA software on the GEA, especially for small (less than 0.5 gram) quantities of plutonium. For calculation of TMU, WRAP has assigned an error factor of $2 \%$ to PFP plutonium isotopics data, although it is known that this is a gross overstatement of the true error. Plutonium mass data from PFP are subject to extra scrutiny. In the past, quantities known to be less than or equal to 1 gram were assigned a value of 1 gram and the known isotopic ratios were applied to render all plutonium mass values. More recently, outgoing waste has been assayed using a segmented gamma scan (SGS) system. The resulting mass values are more accurate, but precedence is still given to WRAP assay values. Other waste streams will be analyzed for AK reliability as they are identified.

\section{Tare Weight Uncertainty}

WRAP assumes that there is no uncertainty associated with the tare weight of drums, drum liners, or packaging material, per internal memo 32B00-PJC-99-004, from the Hanford TRU Waste Project Office. This conclusion is based on discussions with representatives of the DOE Carlsbad Area Office. The following weights are assigned, with no uncertainty:

$\begin{array}{ll}55 \text { gallon (208 liter) drum -- } & 29.0 \mathrm{~kg} \\ \text { Rigid drum liner -- } & \text { As determined by NDE results } \\ \text { Liner bag -- } & 0.4 \mathrm{~kg}\end{array}$




\section{Other Measurement Uncertainties}

There are none of significance.

\section{Propagation of Errors}

Each source of error analyzed above is statistically independent of the others. Propagation of errors becomes a simple matter of combining them in quadrature. In a case of direct addition or subtraction of measurements, this means simply taking the "root of the sum of the squares" of the uncertainties in question to provide the resultant uncertainty. In the case of multiplication or division of measured quantities with associated uncertainties, the root of the squares of the fractional uncertainties provides the final uncertainty. 


\section{References}

1. Passive Nondestructive Assay of Nuclear Materials, Edited by Doug Reilly, Norbert Ensslin and Hastings Smith, Jr., Report NUREG/CR-5550, March 1991.

2. Model S43I Genie-PC Gamma Waste Assay Software Users Manual, Canberra Industries, 1999.

3. Total Measurement Uncertainty for the Canberra Segmented Gamma Scanner System, Canberra Industries, April 1999. PROPRIETARY

4. Total Measurement Uncertainty Assessment for Transuranic Waste Shipments to the Waste Isolation Pilot Plant, K.C. Smith, R. A. Stroud, K.L. Coop and J.F. Bresson, DOE Contract No. DE-AC04-95AL89446, no date.

5. Drum Weight Measurement Uncertainty Review Findings, HNF-3954, M.P. Lane, February, 1999 